\title{
Problems Related to Surgery and Pathology in Lip Cancer Patients and Their Management
}

\section{Dudak Kanseri Hastalarinda Cerrahi ve Patolojiye İlişkin Sorunlar ve Yönetimi}

\author{
๑Tugba Gun Koplay', DMehtap Karamese² \\ 'Konya City Hospital, Department of Plastic Reconstructive and Aesthetic Surgery, Konya, Turkey \\ ${ }^{2}$ Selcuk University, Faculty of Medicine, Department of Plastic Reconstructive and Aesthetic Surgery, Konya, Turkey
}

\begin{abstract}
Purpose: Lip cancers are the second most common cancers of head and neck region. Due to its functional and aesthetic consequences and aggressive course, clinical approach including surgical margins, type of neck dissection and reconstruction techniques are debated topics in lip cancer. We investigated reliability of preoperative evaluations, pathological risk factors for recurrence or metastasis, surgery related morbidities and their management.

Material and Method: The records of patients with basal cell carcinoma (BCC) and squamous cell carcinoma (SCC) were reviewed retrospectively. Demographic data of the patients were evaluated, the reliability of the punch biopsy and radiological imaging was discussed and the effects of pathological features on the risk of recurrence and metastasis was investigated. Surgery related morbidities were revealed. All these problems and their solutions were discussed in the light of literature.

Results: Punch biopsy was found unreliable in this study. Relapses were associated with advanced stage and perineural invasion while cervical metastasis was related with the size of the specimen and surgical margins. Donor site morbidities were higher in local flaps. Recurrence or metastases were not observed in patients who were treated with extensive excision, neck dissection and reconstruction with free flap.

Conclusions: Early diagnosis and functional and aesthetic repair are the most important factors in terms of prognosis in lip cancer. First surgery is very important that determines the prognosis. As the stage progresses, the surgery becomes complex but prognosis can be as good as early stages with good clinical approach.
\end{abstract}

Keywords: Lip, cancer, prognosis, reconstruction, techniques
Öz

Giriş: Dudak kanserleri baş boyun bölgesinde ikinci sıklıkta görülen kanserlerdir. Fonksiyonel ve estetik sonuçları ve agresif seyri sebebiyle cerrahi eksizyon sınırları, boyun diseksiyonu tipi ve rekonstrüksiyon seçenekleri gibi klinik yaklaşım tipleri dudak kanseri hakkında tartışılan konulardır. Çalışmada cerrahi öncesi yapılan değerlendirmelerin güvenilirliği, rekürrens ve metastaz için risk faktörleri, cerrahiye bağlı morbiditeler ve tedavileri araştırıldı.

Gereç ve Yöntem: Kliniğimizde tedavi edilen bazal hücreli karsinom ve squamoz hücreli karsinom tanılı hastaların verileri retrospektif olarak tarandı. Hastaların demografik verileri değerlendirildi, punch biyopsi ve radyolojik görüntülemelerin güvenilirliği tartışıldı ve patolojik özelliklerin rekürrens ve metastaz risk üzerine etkileri araştıııldı. Cerrahi sonrası morbiditeler değerlendirilerek tüm bu problemler ve çözüm yolları literatür eşliğide tartışıldı.

Sonuç: Bu çalışmada punch biyopsi güvenilir bulunmadı. Rekürrensler ileri evre ve perinöral invazyon ile, servikal metastazlar ise çıkartılan lezyon boyutu ve cerrahi sınır ile ilişkili bulundu. Lokal fleplerde donor alan morbiditeleri daha yüksekti. Geniş eksizyon, boyun diseksiyonu ve serbest flep ile rekonstrüksiyon yapılan hasta grubunda rekürrens veya metastaz gözlenmedi.

Tartışma: Erken tanı ve fonksiyonel-estetik onarım dudak kanseri prognozunda en önemli faktörlerdir. Yapılan ilk cerrahi prognozu belirlediğinden çok önemlidir. Evre ilerledikçe cerrahi kompleksleşir fakat iyi bir klinik yaklaşım ile erken evreler kadar iyi bir prognoz sağlanabilir.

Anahtar Kelimeler: Dudak, kanser, prognoz, rekonstruksiyon 


\section{INTRODUCTION}

Lip carcinoma is one of the most common type of malignant tumors of head and neck region, with an incidence of 1.8 per $100,000{ }^{[1]}$ While melanoma is very rare, the most common histopathological type in lip cancer is squamous cell carcinoma (SCC) and it is more aggressive when located on lips compared to other cutaneous parts of head and neck region. ${ }^{[2,3]}$ Due to its functional and aesthetic consequences and aggressive course, clinical approach including surgical margins, type of neck dissection and reconstruction techniques are debated topics in lip cancer.

When surgery, radiotherapy, chemotherapy are used together or alone in the treatment, the first and the main treatment method is surgical excision. Radiotherapy can be used to treat small cutaneous lesions at early stages or in patients at high risk for operation or who do not accept the surgery. ${ }^{[4]}$

First surgery is very important that determines the prognosis; excision with clean surgical margins and neck dissection in the advanced stages are highly important. To remove the tumor safely, it is recommended to plan the tumor-free surgical margins at least $10 \mathrm{~mm} \cdot{ }^{[5]}$ On the other hand, Babington et all reported ideal margins as $4-5 \mathrm{~mm}$ and offered adjuvan radiotherapy if the goal is not achieved. ${ }^{[6]}$

Lymph node metastasis rates range from 3 to $29 \%$. While some authors prefer to do elective node dissection for all patients, others choose to do for only clinical node positive patients. ${ }^{[7]}$ Five percent of patients, who have not undergone neck dissection due to negative clinical and imaging findings, present with recurrences in the neck region later. ${ }^{[8]}$ Sentinel node dissection is recommended for node-negative lip SCC as a safe and feasible procedure. ${ }^{[9]}$ It is recommended to do elective node dissection for tumors larger than $3 \mathrm{~cm}$; and selective node dissection in perineural invasion and low differentiation. ${ }^{[10,11]}$ However, there is still no consensus in this topic. Surgeons choose 'overtreatment' or 'wait and see'.

The best reconstruction technique should be selected according to the defect. The main goal in reconstruction is to provide a functional and aesthetic repair. The aim of our study was to evaluate patients who were admitted to our clinic with lip cancer and to obtain demographic properties of the patients, determinate the location, type, differentiation and stage of the tumors, address the reliability of preoperative radiologic images and punch biopsies, asses the regional metastasis and local recurrence rates according to the pathological features, assess local and other morbidities according to surgical procedure including excision, reconstruction techniques and neck dissection, compare all these problems and their managements with literature.

\section{MATERIAL AND METHOD}

The records of 66 patients with malign lip tumors were retrospectively reviewed after the approval of local Ethics Committee and in compliance with the Declaration of Helsinki.
Malignant melanoma or any other tumors in any part of the body or who receive chemotherapy and/or radiotherapy, also patients with concomitant diseases were excluded to be able to discuss only surgery and pathology related problems. Minimum follow-up time was two years.

Age and sex of the patients were obtained as demographic properties. Location, type, differentiation and stage of the tumors were determined.

The reliability of punch biopsy and preoperative ultrasonographic (USG) results were investigated by comparing with last pathology results.

Pathological features including tumor type, size, distance to surgical margins, presence of perineural invasion, differentiation, and stage were compared with lymph node metastases and recurrence rates.

Microstomies, commissural deterioration, vestibular insufficiency, drooling, donor-side morbidities were evaluated by comparing the types of flaps used for reconstruction according to the defect. Presence of hemorrhage, embolism, or nerve injury, fistula, recurrence rates were evaluated related to neck dissection.

All statistical analyses were performed in two ways using SPSS 15 (IBM Inc, USA) software. Nonparametric assessments were performed by Mann-Whitney $U$ test for numerical data in comparison between independent data groups, and categorical data were compared by Fisher's Chi-square test. Student $t$ test was used to compare survival rates between independent data groups. Two-tailed $p$ values $<0.05$ were considered significant.

\section{RESULT}

41 men and 25 women (mean age: 65.6 years) were included in the study. Regarding the location; $77 \%$ of the tumors were in lower lip and $94 \%$ of those were SCC. In the upper lip, $87 \%$ of the patients had SCC and the remaining 13\% had BCC. Lip tumor location was in 29\% medial, 26\% left lateral and $45 \%$ right lateral region.

According to the staging system defined by the $7^{\text {th }}$ edition of the American Joint Committee on Cancer (AJCC), $64 \%$ of patients were stage $1,17 \%$ of patients were stage $2,4 \%$ of patients were stage 3 , and $11 \%$ of patients were stage $4 a{ }^{[12]}$ When patients pathological results were evaluated in terms of differentiation grade; $63 \%$ were well, $34 \%$ were moderate, and $3 \%$ were less differentiated.

There were three false possitive and one false negative results of preoperative USG investigation about metastatic lenf nodes comparing the last pathology results.

In $55 \%$ of 20 patients who underwent punch biopsy of $4 \mathrm{~mm}$ in diameter were compatible with the actual pathology; while $45 \%$ were incompatible.

There was no significant difference between patients with punch compatible and incompatible results according to the stage $(p=0.722)$ and tumor type $(p=0.596)$. It was observed 
that the patients whose punch biopsy results were not clearly distinguished and/or resulted with benign lesions, returned to the clinic with recurrence within 12 months.

Properties of the patients and risk factors for recurrence, properties of the patients and risk factors for cervical lymph node metastasis were described in Table 1-4.

We defined the surgical margins minimum $5 \mathrm{~mm}$ for BCC and $10 \mathrm{~mm}$ for SCC. In our study, pathological margin was positive in 5 patients $(7.57 \%)$ who underwent excision with a minimum of $1 \mathrm{~cm}$ limit and required re-excision. For this reason, factors such as tumor size, the time passed since the lesion appeared, and the presence of LAP were evaluated from the patients who applied to our clinic, and excision is performed with a $2 \mathrm{~cm}$ surgical margin for the patients who were in advanced stages.

Minimum follow-up time was two years in this study. At second year overall survival (OS) rate was $90.9 \%$ and disease free survival (DFS) rate was $80.3 \%$, locoregional recurrence-free survival (LRFS) rate was $80.3 \%$. Recurrence was seen in nine patient and locoregional metastasis was seen in 6 patient within the first two years. Recurrence was more frequent in patients with advanced stage (sig. $=0.041<p$ value $=0.05$ ) and perineural invasion (sig. $=0.009<p$ value 0.05 ) and locoregional metastasis was proportional to the size of the specimen $($ sig. $=0.014<p$ value $=0.05$ ) and proximity to the surgical border (sig. $=0.025<p$ value $=0.05$ ).

\section{Table 1. Properties of the patients with recurrence}

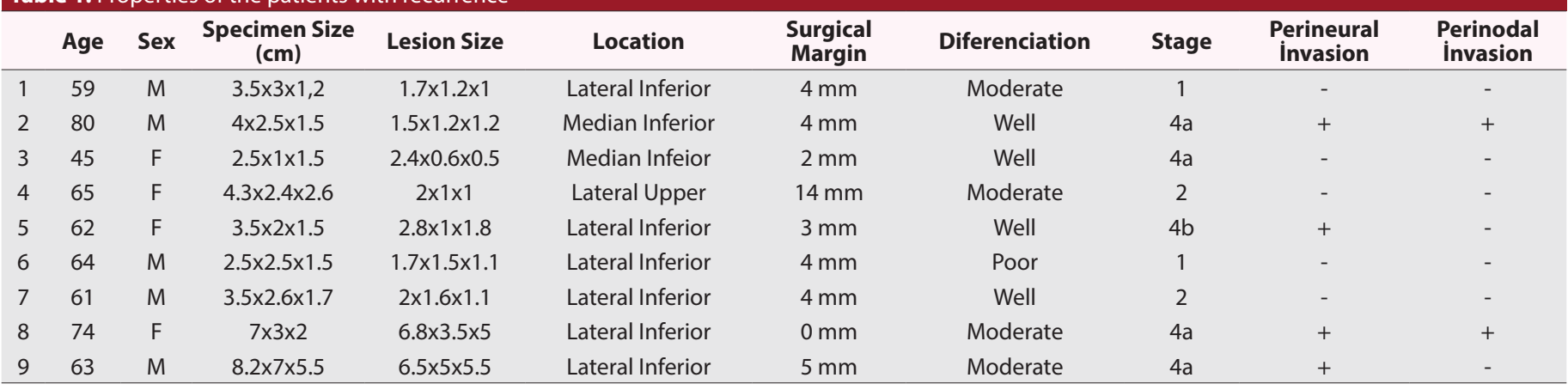

\section{Table 2. Risk factors for recurrence}

\begin{tabular}{|c|c|c|c|}
\hline & Recurrence + & Recurrence - & $P$ value \\
\hline Specimen size & $496.240 \mathrm{~mm}^{3}(\mathrm{SD} \pm 108.89)$ & $102.260 \mathrm{~mm}^{3}(\mathrm{SD} \pm 62.35)$ & sig. $=0.782>p$ value $=0.05$ \\
\hline Lesion size & $66.214 \mathrm{~mm}^{3}(\mathrm{SD} \pm 35.11)$ & $35.424 \mathrm{~mm}^{3}(\mathrm{SD} \pm 11.93)$ & sig. $=0.333>p$ value $=0.05$ \\
\hline Surgical Margin & $3 \mathrm{~mm}(\mathrm{SD} \pm 2.646)$ & $5.02 \mathrm{~mm}(\mathrm{SD} \pm 4.102)$ & sig. $=0.162>p$ value $=0.05$ \\
\hline Stage & $2.56(\mathrm{SD} \pm 1.424)$ & $1.8(\mathrm{SD} \pm 1.142)$ & sig. $=0.041<p$ value $=0.05$ \\
\hline Location & 8 inferior, 1 upper & 14 upper, 43 infeior & sig. $=0.58>p$ value 0.05 \\
\hline Pathologic type & $8 \mathrm{SCC}, 1 \mathrm{BCC}$ & $15 \mathrm{BCC}, 42 \mathrm{SCC}$ & sig. $=0.07>p$ value 0.05 \\
\hline Perineural invasion & $4(+), 5(-)$ & $5(+), 52(-)$ & sig. $=0.009<p$ value 0.05 \\
\hline
\end{tabular}

\section{Table 3. Properties of the patients with cervical lymph node metastasis}

\begin{tabular}{|c|c|c|c|c|c|c|c|c|c|c|}
\hline & Age & Sex & $\begin{array}{l}\text { Specimen Size } \\
(\mathbf{c m})\end{array}$ & Lesion Size & Location & $\begin{array}{l}\text { Surgical } \\
\text { Margin }\end{array}$ & Diferenciation & Stage & $\begin{array}{c}\text { Perineural } \\
\text { Invasion }\end{array}$ & $\begin{array}{c}\text { Perinodal } \\
\text { İnvasion }\end{array}$ \\
\hline 1 & 78 & $\mathrm{~F}$ & $4 \times 3.5 \times 2$ & $3 \times 3 \times 2$ & Lateral Upper & $5 \mathrm{~mm}$ & Moderate & 2 & - & - \\
\hline 2 & 56 & $\mathrm{~F}$ & $7.5 \times 3.5 \times 1,3$ & $5.8 \times 2.9 \times 1.1$ & Median Inferıor & $2 \mathrm{~mm}$ & Moderate & $4 b$ & - & - \\
\hline 3 & 69 & $M$ & $1.3 \times 1.2 \times 0.8$ & $1.1 \times 1 \times 0.7$ & Median Inferior & $1 \mathrm{~mm}$ & Well & 1 & - & - \\
\hline 4 & 54 & $M$ & $1.4 \times 0.6 \times 0.5$ & $0.7 \times 0.6 \times 0.5$ & Median Inferior & $0 \mathrm{~mm}$ & Well & 1 & - & - \\
\hline 5 & 58 & $\mathrm{~F}$ & $2 \times 1.8 \times 1.3$ & $0.6 \times 0.5 \times 0.5$ & Lateral Inferior & $5 \mathrm{~mm}$ & Well & 1 & - & - \\
\hline 6 & 54 & $M$ & $2.5 \times 1.3 \times 1$ & $2.1 \times 0.7 \times 0.4$ & Median Inferior & $0 \mathrm{~mm}$ & Well & 2 & - & - \\
\hline
\end{tabular}

Table 4. Risk factors for cervical lymph node metastasis

\begin{tabular}{lccc} 
& Metastasıs + & Metastasıs - & P value \\
\hline Specimen size & $1287.020 \mathrm{~mm}^{3}(\mathrm{SD} \pm 493.89)$ & $101.728 \mathrm{~mm}^{3}(\mathrm{SD} \pm 46.61)$ & sig. $=0.014<\mathrm{p}$ value $=0.05$ \\
Lesion size & $44.465 \mathrm{~mm}^{3}(\mathrm{SD} \pm 16.99)$ & $8.657 \mathrm{~mm}^{3}(\mathrm{SD} \pm 5.59)$ & sig. $=0.504>\mathrm{p}$ value $=0.05$ \\
Surgical Margin & $2.43 \mathrm{~mm}(\mathrm{SD} \pm 2.225)$ & $5.02 \mathrm{~mm}(\mathrm{SD} \pm 4.058)$ & sig. $=0.025<\mathrm{p}$ value $=0.05$ \\
Stage & $2.14(\mathrm{SD} \pm 1.345)$ & $1.90(\mathrm{SD} \pm 1.199$ & sig. $=0.623<\mathrm{p}$ value $=0.05$ \\
Location & 5 inferior, 1 upper & 14 upper, 46 infeior & sig. $=0.95>\mathrm{p}$ value 0.05 \\
Pathologic type & $6 \mathrm{SCC}$ & $16 \mathrm{BCC}, 44 \mathrm{SCC}$ & \\
Perineural invasion & $6(-)$ & $9(+), 57(-)$ & \\
\hline
\end{tabular}


For reconstruction; primary closure (37.5\%), local flaps (33\%), regional flaps (12.5\%) and free flaps (radial forearm fasciocutaneous, split rectus muscle (Figure 1), fibula ossecutaneous, DIEP fasciocutaneous) (16.6\%) were used according to the defect size and location. Among the patients who underwent reconstruction with free flaps; one was having stage 1 disease, three were stage 2 , three were stage 3 , two were $4 a$, and one was $4 b$ and three of them were with recurrences. No microstomies were observed except one patient who was repaired with a free split rectus muscle flap. There was no drooling in any of the patients whose commissure was preserved and that reconstructed with free radial forearm flap containing palmaris longus. Tendon exposures at radial forearm flap donor area were repaired with ulnar artery based perforator flap in 2 patients. Sensory loss was observed in 2 patients treated with Eslander flap, and drooling was observed in a patient who was treated with Gilles flap. Orocutaneous fistula was determined in 2 patients; one was repaired by classical methods; the other was controlled by early Botulinum toxin injections.

We used tongue flap for one patient with vestibular sulcus insufficiency that was reconstructed with local flap; and applied horizontal incision and vertical suturation for the other. K-M plasty was required in 2 patients complained of microstomies after reconstruction with Gilles and free split rectus muscle flap. Five patients with mandibular invasion were treated with bone graft after segmental mandibulectomy; one patient was treated with reconstruction plate alone, and one patient with free fibula flap.
Neck dissection was performed during the initial surgery in 16 patients with SCC. While there were no recurrences in longterm in the patients who had neck dissection; neck dissection was not present in any of the patients who had metastasis in follow-up. No complications such as intraoperative hemorrhage, embolism, or nerve injury occurred in any of the patients, while there was chylous fistula in 2 patients, and they were spontaneously dropped back with fat free diet.

\section{DISCUSSION}

The lip is an important aesthetic unit in the lower $1 / 3$ of the face and an essential structure for many functions such as eating, drinking, speaking and laughing. The most common lip cancer type is SCC, originating from epithelium. ${ }^{[13]}$ Lip cancer requires a good clinical approach due to its aggressive course. Early diagnosis and adequate treatment are the most important factors in terms of prognosis. USG is useful in evaluating the spread to neck soft tissues and lymph nodes. Computed tomography (CT) is more valuable in evaluating invasion into bone structures. ${ }^{[14]}$ Immunological agents can be used in the treatment. ${ }^{[15]}$ However, definitive treatment is provided by surgery.

In literature, $75 \%$ of the patients diagnosed with lip cancer are over 50 years old. ${ }^{[16]}$ In our study, the average age of the patients was 65.6 years. Our results were compatible with the previous literature. However, in the literature, male to female ratio was reported as $6-8 / 1$, but in our study $62 \%$ of the patients were male which was a highly lower ratio compared with the literature. ${ }^{[17]}$
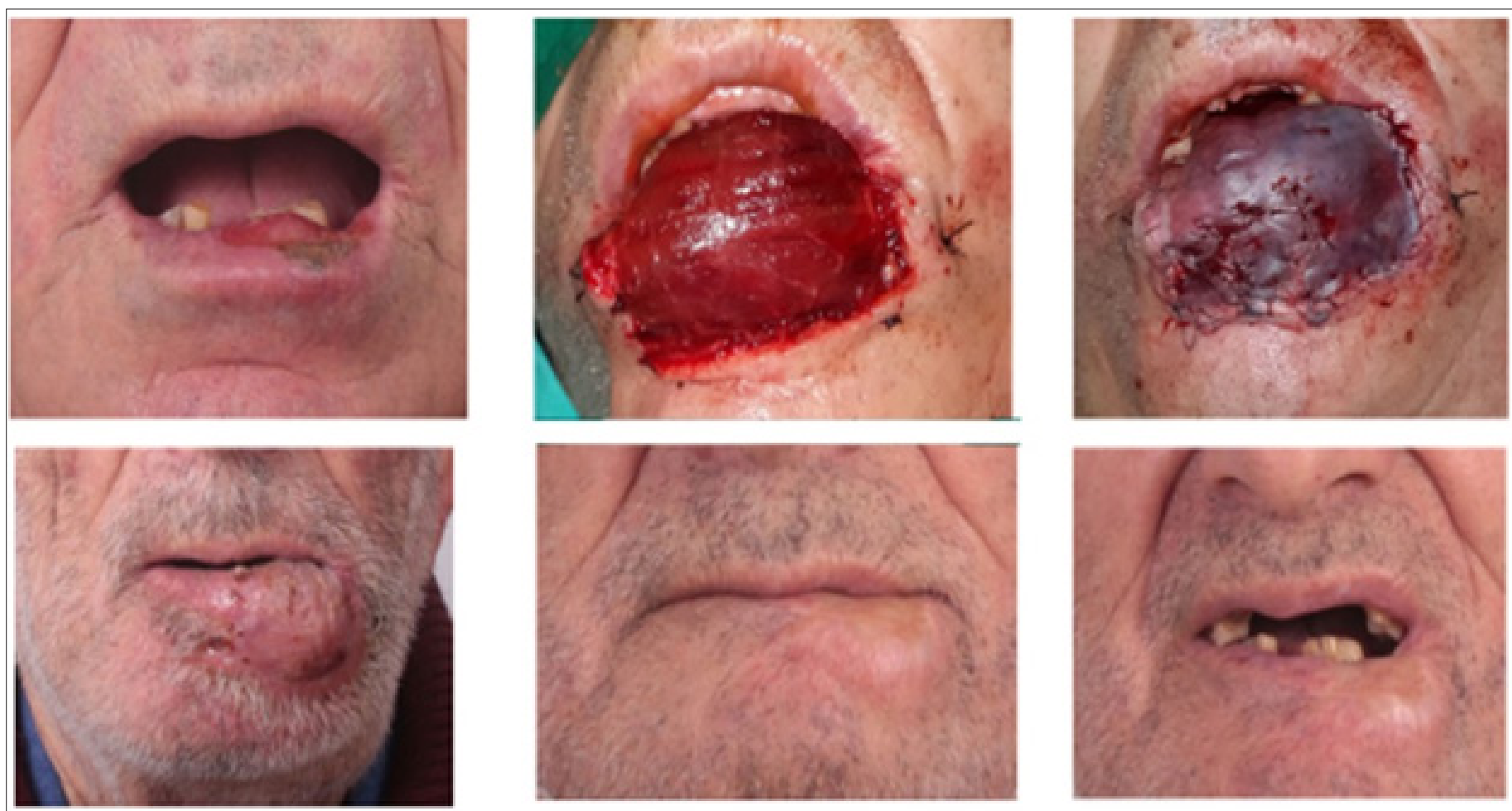

Figure 1. Reconstruction of the defect at lower lip with free split rectus abdominis muscle flap, contruction at the flap at long-term follow-up 
Salgarelli and colleagues found that $80-95 \%$ of the lesions were at lower lip, $2-12 \%$ of them were at upper lip, and 1-15\% of them were in the commissure in the patients with lip cancer. ${ }^{[18]}$ In our study, $77 \%$ of the patients with lip cancer had lower, $23 \%$ had upper lip localizations, which was compatible with the literature.

While SCC is most commonly located in lower lip, BCC is seen most frequently in upper lip. ${ }^{[19]}$ In our study, consistent with the literature there were $13 \%(n=2)$ SCC and $87 \%(n=13)$ BCC in the patients with upper lip tumors. Pathological results were SCC in $94 \%(n=48)$ and BCC in $6 \%(n=3)$ of patients with lower lip tumors, compatible with the literature.

Effiom et al. ${ }^{[20]}$ detected poor differentiation in $47.6 \%$ of 233 patients in their studies in Nijeria. It can be diagnosed earlier in developed countries. In our study, $65 \%$ of the patients were at stage $1,16 \%$ were at stage $2,5 \%$ were at stage $3,10 \%$ were at stage $4 a$ and $4 \%$ were at stage $4 b$.

Ultrasonography has been found to be used for the detection of preoperative neck metastases with close sensitivity and specificity compared with computerized tomography and/ or magnetic resonance imaging by Yoon et al. ${ }^{[21]}$ Patients were routinely screened with pre-operative neck USG for the detection of lymphadenopathy (LAP) presence in our clinic. When the results of USG examination and pathology were compared in this study, it was seen that there were three false positive and one false negative results and the difference was not statistically significant.

It has been described that $75 \%$ of local recurrences and metastases of SCCs is seen within 2 years ${ }^{[22]}$ Local recurrence rate in the literature is reported as $5-15 \% \cdot{ }^{[23]}$ In our study, recurrence was observed in $13.6 \%$ in the first two years, statistically related with advanced stage and perineural invasion.

Lymph node metastasis rates range from 3 to $29 \%$ in lip tumor and it is recommended to do elective node dissection for tumors larger than $3 \mathrm{~cm}$; and selective node dissection in perineural invasion and low differenciation. ${ }^{[11,24]}$ In our study, metastasis was observed in $9.09 \%$ in the first two years, statistically related with size of the specimen and proximity to the surgical border.

First surgery is very important that determines the prognosis. To remove the tumor safely, it is recommended to plan the surgical margins at least $10 \mathrm{~mm} \cdot{ }^{[5]}$ In our study, surgical margin was positive in 5 patients (7.57\%) who underwent excision with a minimum of $1 \mathrm{~cm}$ limit and required re-excision. For this reason, factors such as tumor size, the time passed after the first appearance of the lesion, and the presence of LAP were evaluated in patients who applied to our clinic, and excision was performed with a $2 \mathrm{~cm}$ surgical margin.

The main goal in reconstruction is to provide a functional and aesthetic repair. For this purpose there are many options. While reconstruction like with like and short operation time are advantages of local flaps; microstomy, scar formation in the lip, numbness are disadvantages. In reconstruction with free flaps, the tumor excision is performed more courageously, which provides better prognosis with negative surgical margins but donor site morbidity in any other part of the body is disadvantage. Tendon exposures were occurred in two patients at radial forearm flap donor area repaired with ulnar artery based perforator flap.

During reconstruction with local flaps from the opposite lip, flap width should be planned as half of the defect. While the disadvantage of repairing with Abbe flap is requirement of a two stage operation; commissure may be replaced with Eslander flap and as stated by Kroll, commissuroplasty may be required. ${ }^{[24]}$ Defects up to $80 \%$ can be repaired by Gilles flap but microstomy, loss of sensation and oral incubation may take place. ${ }^{[26]}$ Since the neurovascular structures are protected in Karapandzic flap, motor and sensory function is obtained. ${ }^{[27]}$ Sensory loss was observed in 2 patients treated with Eslander flap, and drooling was observed in a patient who was treated with Gilles flap. Orocutaneous fistula was determined in 2 patients; one was repaired by classical methods; the other was controlled by early Botulinum toxin injections. We used tongue flap for one patient with vestibular sulcus insufficiency that was reconstructed with local flap; and applied horizontal incision and vertical suturation for the other. K-M plasty was required in 2 patients complained of microstomies after reconstruction with Gilles and free split rectus muscle flap.

In this study, as the stage progressed, the amount of excision and repair techniques became more complex. Elective or selective neck dissection were applied for all of the patients who were reconstructed with free flap at the same time and no recurrence or metastasis was observed in any of these patients though they were in advanced stages. Through this information, aggressive treatment in lip cancer management could also provide cure in advanced stage.

The disadvantages of repairing with free flaps are the long operation time and insufficient motor and sensory functions after reconstruction. However, radial forearm flap is the most commonly preferred free flap for reconstruction of lip; 2 patients were repaired with free split rectus muscles to obtain motor functions. ${ }^{[28]}$ The disadvantage of this flap is that the duration of the innervation of the muscle is long and some atrophy may occur since the patient's are geriatric. Therefore, flap size should be planned at least $50 \%$ larger than the defect.

\section{CONCLUSION}

The lip is an important aesthetic unit in the lower $1 / 3$ of the face and a necessary structure for many functions such as eating, drinking, speaking, and laughing. Early diagnosis and adequate treatment are the most important factors in terms of prognosis. In the surgical treatment of lip cancer, the tumor should be removed as widely as possible and reconstructed with sufficient tissue to obtain a functional and aesthetically successful result. We believe that as the stage progress, the surgery becomes complex but prognosis can be as good as early stages with good clinical approach. 


\section{ETHICAL DECLARATIONS}

Ethics Committee Approval: The study was carried out with the permission of Selcuk University Ethic Committee (Permission granted: 07.06.2017, Decision no: 70632468050.01.04).

Informed Consent: Because the study was designed retrospectively, no written informed consent form was obtained from patients.

Referee Evaluation Process: Externally peer-reviewed.

Conflict of Interest Statement: The authors have no conflicts of interest to declare.

Financial Disclosure: This study was supported by Selcuk University Research Fund (Project Number: 2017/189).

Author Contributions: All of the authors declare that they have all participated in the design, execution, and analysis of the paper, and that they have approved the final version.

\section{REFERENCES}

1. Zhao R, Jia T, Qiao B, at al. Nomogram predicting long-term overall survival and cancer-specific survival of lip carcinoma patients based on the SEER database. Medicine 2019; 98:e16727.

2. Singer S, Zeissig SR, Emrich K, Holleczek B, Kraywinkel K, Ressing M. Incidence of lip malignancies in Germany: Data from nine populationbased cancer registries. J Oral Pathol Med 2017; 46:780-5.

3. Kristensen RN, Andersen PS, Andersen JL. Lip carcinoma: clinical presentation, surgical treatment, and outcome: a series of 108 cases from Denmark, Journal of Plastic Surgery and Hand Surgery 2017;51:342-7.

4. Ho T, Byrne PJ. Evaluation and initial management of the patient with facial skin cancer. Facial Plast Surg Clin North Am 2009;17:301-7.

5. Bilkay U,Kerem H, Ozek C, et al. Management of Lower Lip Cancer: A Retrospective Analysis of 118 Patients and Review of the Literature. Ann Plast Surg 2003; 50:43-50.

6. Babington S, Veness MJ, Cakir B et al. Squamous cell carcinoma of the lip: is there a role for adjuvan radiotherapy in improving local control following incomplete or inadequate excision? ANZ J Surg 2003; 73: 621-5.

7. Wermker K, Belok F, Schipmann S, Klein M, Schulze HJ, Hallermann C. Prediction model for lymph node metastasis and recommendations for elective neck dissection in lip cancer. Journal of Cranio-Maxillo-Facial Surgery 2015; 1-8.

8. Keravala $C, T$ Roques $T$, Jeannon $P$, Bisase B. Oral cavity and lip cancer: United Kingdom National Multidisciplinary Guidelines. J Laryngol Otology 2016; 130: 83-9.

9. Hokkam E, Gomaa A, Rifaat M, et al. The Role of sentinel lymphnode biopsy in managing lip squamous cell carcinoma patients without clinical evidence of nodal metastasis. Gulf J Oncolog 2013;1:57-62.

10. Olgun Y, Durmusoğlu M, Dogan E, Erdag TK, Sarıoglu S, İkiz AO. Role of Elective Neck Dissection in Early Stage Lip Cancers. Turk Arch Otorhinolaryngol 2015; 53: 23-5.

11. Bota JP, Lyons AB, MD, Carroll BT. Squamous Cell Carcinoma of the Lip: A Review of Squamous Cell Carcinogenesis of the Mucosal and Cutaneous Junction. Dermatol Surg 2017;43:494-506.

12. Edge SB, Compton CC. The American Joint Committee on Cancer: the 7th edition of the AJCC cancer staging manual and the future of TNM. Ann Surg Oncol 2010;17:1471-4.

13. Vukadinovic $M$, Jezdic Z, Petrovic M, Medenica LM, Lens M. Surgical management of squamous cell carcinoma of the lip: analysis of a 10-year experience in 223 patients. J Oral Maxillofac Surg 2007;65:675-79.

14. Bombeccari GP, Candotto V, Giannì AB, Carinci F, Spadari F. Accuracy of the Cone Beam Computed Tomography in the Detection of Bone Invasion in Patients With Oral Cancer: A Systematic Review. Eurasian J Med 2019;51:298-306.
15. Simsek M, Tekin SB, Bilici M. Immunological Agents Used in Cancer Treatment. Eurasian J Med 2019;51:90-4

16. Blomberg M, Nielsen A, Munk C, Kjaer SK. Trends in head and neck cancer incidence in Denmark, 1978-2007: Focus on human papillomavirus associated sites. Int J Cancer 2011; 129: 733-41.

17. Regezi J,Sciubba J Oral Pathology. Clinical -Pathologic Correlations. Philedelphia,PA : Saunders; 1994.p 79-84.

18. Salgarelli AC, Sartorelli F, Cangiano A, Pagani R, Collini M. Surgical treatment of lip cancer: our experience with 106 cases. J Oral Maxillofac Surg $2009 ; 67: 840-5$.

19. Silapunt S, Peterson SR, Goldberg LH. Basal Cell carsinoma on the vermilion lip: a study of 18 cases J Am Acad Dermatology 2004;50:384-7.

20. Effiom OA, Adeyemo WL, Omitola OG, Ajayi OF, Emmanuel MM, Gbotolorun OM. Oral squamous cell carcinoma: a clinicopathologic review of 233 cases in Lagos, Nigeria. J OralMaxillofac Surg 2008;66:15959.

21. Yoon DY, Hwang HS, Chang SK, et al. CT, MR, US, 18FFDG PET/CT, and their combined use for the assessment of cervical lymph node metastases in squamous cell carcinoma of the head and neck. Eur Radiol 2009;19:63442.

22. Jennings $L$, Schmults CD. Management of high-risk cutaneous squamous cell carcinoma. J Clin Aesthet Dermatol 2010;3:39-48.

23. Yılmaz S, Ercocen AR. Selective Neck dissection in T1-2,No patients with Lower Lip Cancer necessary? Ann Plast Surg 2009;62:381-3.

24. Vanderlei JP, Pereira-Filho FJ, da Cruz FA, et al. Management of neck metastases in T2N0 lip squamous cell carcinoma. Am J Otolaryngol 2013; 34: 103-6.

25. Kroll,S (Ed) Lip reconstruction. In Reconstructive Plastic Surgery for Cancer. St. Louis, Mo: Mobsy Year Book,1996;201-9.

26. Calhoun KH, Stiernberg CM. Surgery of the lip. New York (NY): Thieme Medical Publishers; 1992.

27. Neligan PC. Strategies in lip reconstruction. Clin Plast Surg 2009;36:47785.

28. Furuta S, Sukaguchi Y, Imasarva M, et al. Reconstruction of the lips, oral commissure, and full-thickness cheek with a composite radial forearmpalmaris longus free flap. Ann Plast Surg 1994;33:544-7. 